\title{
Sensitivity of the Antarctic sea-ice distribution to oceanic heat flux in a coupled atmosphere-sea-ice model
}

\author{
Xingren Wu, W.F. Budd, ${ }^{2}$ A.P. Worby, ${ }^{1}$ Ian Allison $^{1}$ \\ ${ }^{1}$ Antarctic CRC and Australian Antarctic Division, Box 252-80, Hobart, Tasmania 7001, Australia \\ ${ }^{2}$ Antarctic CRC, Box 252-80, Hobart, Tasmania 7001, Australia
}

\begin{abstract}
A coupled atmosphere-sea-ice model is used to study the sensitivity of the Antarctic sea-ice distribution to oceanic heat flux (OHF). Remote sensing of sea ice from microwave radiometers provides data on ice extent and ice concentration. The ice-thickness data used are from ship-based observations. Our simulations suggest that $\mathrm{OHF}$ values of $0-5 \mathrm{Wm}^{-2}$ will cause sea ice to be too thick in the model. A value of $20-25 \mathrm{Wm}^{-2}$ throughout the year causes sea ice to be too thin in the model. The model results indicate that a seasonally varying $\mathrm{OHF}$ is required to match the modelled thickness with observations. Values of 5-30 $\mathrm{Wm}^{-2}$, with an annual mean of $10-15 \mathrm{Wm}^{-2}$, give a reasonable distribution of sea-ice thickness. This agrees with the limited observations of $\mathrm{OHF}$ available for the Antarctic. The model results also indicate that the OHF should be varied spatially. When a seasonally and spatially variable $\mathrm{OHF}$ is applied to the coupled atmosphere-sea-ice model a still better simulation of the sea-ice distribution is obtained. Our results also suggest that the role of ice advection is very important in the determination of the sea-ice distribution, and it can be quantified by the model.
\end{abstract}

\section{INTRODUGTION}

The Antarctic pack ice plays an important role in global climate and climate change (e.g. Budd, 1991; Hanna, 1996), particularly due to the large seasonal variability in ice extent and thickness, and the presence of leads and polynyas. The heat provided to the underside of the ice from the ocean, the so-called oceanic heat flux (OHF), is very important to ice growth and decay, and a key term in the mass and heat balance of sea ice. However, there are very few direct measurements of the OHF available to date. Allison (1981) and Allison and others (1982) reported an annual mean OHF of $10-15 \mathrm{Wm}^{-2}$ under coastal fast ice near Mawson, with a maximum value up to $40 \mathrm{Wm}^{-2}$ in early winter. Heil and others (1996), using a thermodynamic model, derived an average $\mathrm{OHF}$ of $7.9 \mathrm{Wm}^{-2}$, with an annual mean ranging from 5 to $12 \mathrm{Wm}^{-2}$ for fast ice over the period 1958-86 in the vicinity of Mawson, on the coast of East Antarctica. Gordon and Huber (1990) estimated similar values of $16 \mathrm{Wm}^{-2}$ for the annual average and $41 \mathrm{Wm}^{-2}$ for the winter period along the Greenwich meridian at $60-70^{\circ} \mathrm{S}$. Martinson (1990) obtained results in agreement with those estimated by Gordon and Huber (1990) from an analytic model analysis. Lytle and others (2000) derived an average OHF of $15 \mathrm{Wm}^{-2}$ in the East Antarctic region around $140^{\circ} \mathrm{E}, 64^{\circ} \mathrm{S}$ during August 1995. A high value of winter OHF has also been reported by McPhee and others $(1996,1999)$ in the central Weddell Sea. In the western Weddell Sea the estimated winter OHF is relatively small, only about $7 \mathrm{Wm}^{-2}$ (Lytle and Ackley, 1996) from late February to early June. All of these measurements illustrate the uncertainty of the OHF and its high degree of variability in space and time.

The OHF has been prescribed as a constant in many sea- ice models, due to the lack of observational data (Parkinson and Washington, 1979; Hibler and Ackley, 1983), although in some sea-ice models it is parameterized to be dependent on water temperature (e.g. Ebert and Curry 1993). Values used range from 2 to $25 \mathrm{Wm}^{-2}$. Parkinson and Washington (1979) used a high OHF value of $25 \mathrm{Wm}^{-2}$ to obtain a realistic seasonal cycle of sea-ice distribution in the Southern Hemisphere. However, Hibler and Ackley (1983) used only $2 \mathrm{Wm}^{-2}$ to obtain a realistic seasonal cycle of the Weddell Sea ice when they used daily, rather than monthly, atmospheric forcing. They suggested this was a result of the role of ice dynamics in their model. From simulations of the Southern Ocean ice-ocean system, using a coupled ice-ocean model with atmospheric data forcing from the European Centre for Medium-range Weather Forecasts climatology, Häkkinen (1995) suggested that the averaged OHF in the Weddell Sea is $<20 \mathrm{Wm}^{-2}$. Geiger and others (1997) also demonstrated that a constant value of $20 \mathrm{Wm}^{-2}$ of OHF is too high for the Weddell Sea. They showed that the use of a higher value in the east than in the west, and higher in winter than in summer, based on observations, produced a better simulation of the seasonal cycle of the Weddell Sea ice.

Ideally, the OHF should be able to be calculated as a residual based on the energy and mass conservation over the sea-ice zone and it should be diagnostic in a fully coupled ocean model. However, the existing datasets acquired from observations do not cover adequately the complete seasonal cycle within the Antarctic sea-ice zone. Fully coupled models usually need to include ocean surface heat-flux corrections to avoid climatic drift, and also require long computation time to reach equilibrium climates. In this study we test the sensitivity of the simulated Antarctic sea-ice distribution to OHF in a coupled atmosphere-sea-ice 
model. The sea-ice model is an extension of the model of $\mathrm{Wu}$ and others (1997) and includes an ice-thickness-dependent rafting scheme in the ice dynamics (Worby and $\mathrm{Wu}, 1998$; Wu and others, 1999). The sea-ice distributions modelled for different prescribed OHF values are compared with observations. Passive-microwave remote sensing of sea ice provides data on ice extent, ice concentration and openwater fraction. Ice-thickness data have been obtained from in situ ship-based observations.

\section{MODEL DESGRIPTION}

\subsection{Melbourne University GGM}

The atmospheric model used here is the Melbourne University 21-wave (R21) 9-level general circulation model (GCM) (Simmonds, 1985). It includes a surface-layer parameterization based on Monin-Obukhov similarity theory and has been shown to produce creditable simulations of climate both globally and in the polar region (e.g. Simmonds, 1990; Boer and others, 1992), including simulation of the sea-ice characteristics (Budd and others, 1997).

\subsection{Sea-ice model}

The sea-ice model is a global dynamic-thermodynamic model, discussed in detail in Wu and others (1997, 1999). Its thermodynamic representation is similar to that of the Parkinson and Washington (1979) model. There is one mixed layer $(50 \mathrm{~m})$ in the ocean, one ice layer, one snow layer, and the atmospheric boundary layer is the lowest layer of the GCM. The boundary-layer scheme, based on similarity theory, is described by Simmonds (1985). The application of this formulation to an ice-ocean mixture including the treatment of separate radiation balances for ice and water is described by Simmonds and Budd (1990). Changes of thickness and concentration in sea ice and/or snow are based on the energy balances at the surface, ice/water interface and the open-water area within the ice.

The surface temperature (for either snow or ice) is calculated from the net flux of energy from radiation, sensible-heat flux, heat of sublimation and conductive-heat flux. Melting occurs if the surface temperature reaches the melting point $(273.15 \mathrm{~K})$. The albedo for ice and snow is parameterized as a function of ice thickness, snow depth and surface temperature (Wu and others, 1997). This scheme performs well in comparison with observations of Antarctic sea-ice albedo (e.g. Allison and others, 1993; personal communication from S. Warren, 1997).

At the ice/water interface, the energy absorbed or released by ice melting or freezing, respectively, balances the energy flux of the OHF and the conductive heat flux through the ice. Dealing with an under-determined set of parameters, the OHF is prescribed in the model. In the following this variable is assessed within the coupled system. Within leads, the partitioning of the freezing or melting to the sides or the bottom of the ice is parameterized. This is related to ice thickness and the open-water fraction, as described by Wu and others (1997).

A "snow-ice" formulation is also included, following that of Ledley (1985). Snow ice is formed at the snow/ice interface when snow depresses the ice below the waterline, and flooding occurs to form a saline ice-and-snow mixture.
The dynamics of the model is similar to, but simpler than, that of the "cavitating-fluid" version of Flato and Hibler (1992), with only the compressive stresses effective in the sea ice. A simple ice-rheology scheme is used here (Wu and others, 1997). At low ice concentration (no interaction between floes), the sea ice moves in free drift forced by the wind. The $2 \%$ rule is applied (the "Nansen rule" for free ice drift) and a turning angle of $25^{\circ}$ is incorporated which is to the left in the Southern Hemisphere. The resistance of sea ice is considered at high ice concentrations where the floes start to interact significantly and exert pressure on each other (e.g. Crane and Wadhams, 1996), and we include a parameterization of the rafting processes which is dependent on ice thickness and open-water fraction (Wu and others, 1999). This is modified from the model of Wu and others (1997).

The ice-model physical grid is identical to the grid of the atmospheric GCM. Its resolution is approximately $3.3^{\circ}$ lat. $\times 5.6^{\circ}$ long.

\section{DATASETS FOR VALIDATION}

The observational data for sea-ice concentration are derived from satellite observations: the Special Sensor Microwave/ Imager (SSM/I) from July 1987 to June 1995. These data provide daily global coverage of the Antarctic sea-ice zone. However, there is still considerable uncertainty in the climatology with regard to the global sea-ice cover because of its large regional and interannual variability, the uncertainties in the radiance to ice-concentration algorithm, and the relatively short period of global data available (Cavalieri and others, 1997; Comiso and others, 1997).

The sea-ice thickness data used here are primarily from in situ observations from 18 voyages to the East Antarctic pack-ice zone between 1986 and 1995. The observations were made hourly from the ship's bridge using a technique described by Worby and others (1998). For each observation the pack is divided into three thickness categories, and the concentration, mean thickness, floe size, topography and snow cover are estimated for each category. The dataset covers the months March-April and August-December. The monthly ice- and snow-thickness distributions from these data are presented in Worby and others (1998).

\section{SIMULATION RESULTS}

The coupled atmosphere-sea-ice model described in section 2 was used to simulate the seasonal cycle of the global seaice distribution, but it is the Antarctic simulation which forms the primary focus of this paper. To study the sensitivity of the Antarctic sea-ice distribution to $\mathrm{OHF}$ in the coupled atmosphere-sea-ice system, we run the model using prescribed OHF of $0,5,10,15,20$ and $25 \mathrm{Wm}^{-2}$ (hereafter $\mathrm{OHF} 0, \ldots, \mathrm{OHF} 25)$. The $\mathrm{OHF}$ is fixed at these values through the whole year within the ice-covered area (i.e. whenever sea ice exists the OHF is applied). We have also run the coupled model with prescribed seasonally and spatially variable $\mathrm{OHF}$ based on limited available observations as shown in Table 1 . In this run the $\mathrm{OHF}$ is varied to be higher in winter and lower in summer, and is set higher in the central and eastern Weddell Sea $\left(35^{\circ} \mathrm{W}-20^{\circ} \mathrm{E}\right)$, than over the other regions, with the minimum in the western Weddell Sea $\left(60-35^{\circ} \mathrm{W}\right)$. We have also used higher $\mathrm{OHF}$ in the western Ross Sea $\left(160^{\circ} \mathrm{E}-160^{\circ} \mathrm{W}\right)$. This is based on the residual ice in the constant-flux cases. The variable heat-flux 

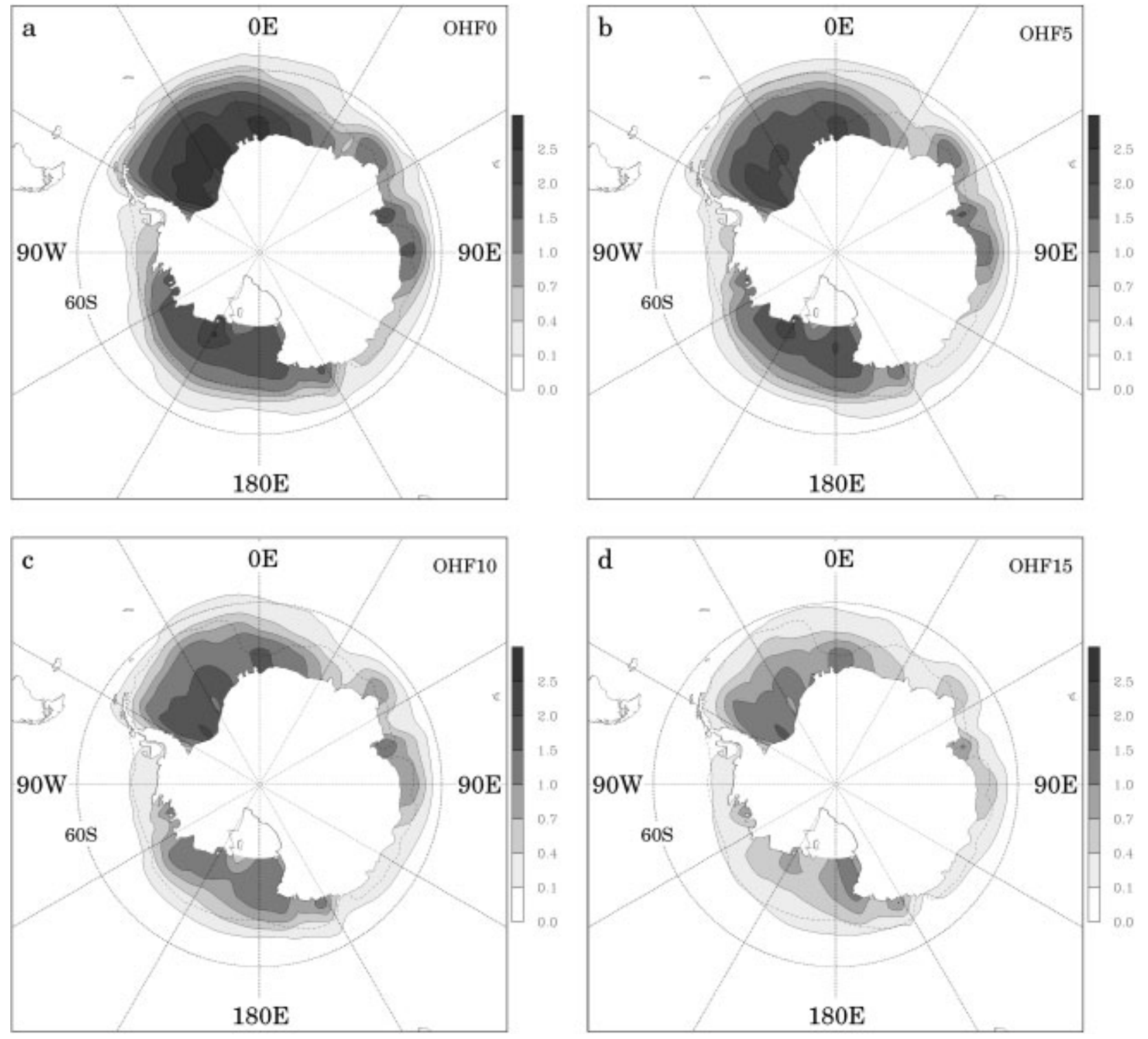

Fig. 1. Simulated sea-ice thickness ( $m$ ) for December-February (DFF) average for ( a) OHF0, (b) OHF5, (c) OHF10 and (d) OHF15. The dashed line is the observed (SSM/I 1987-95 average) sea-ice edge (defined as 15\% sea-ice concentration).

experiment is referred to as VAR. To gain an appreciation of the importance of the role played by ice advection in the sea-ice model, we have also performed an experiment using the same OHF as in VAR but without ice advection (i.e. using thermodynamics only). This experiment is referred to as VART. All experiments were run for 6 years with the same initial conditions from an early quasi-equilibrium simulation. The results presented here are from the 4 year average from years 3-6 of the simulations (the first 2 years' results are treated as adjustment).

The sea-ice extent, which is defined as the area with sea ice present (including open water) for which each gridcell has at least $15 \%$ sea-ice concentration, is very sensitive to the $\mathrm{OHF}$ in late spring and summer, but less so for the rest of the season. The simulations for VAR and OHF15 compare well with observations, but for OHF0-OHF10 and VART there is too

Table 1. The prescribed seasonally variable OHF used in the VAR and VART experiments for seven sectors of Antarctic ice cover

\begin{tabular}{|c|c|c|c|c|c|}
\hline & $\begin{array}{l}\text { Spring } \\
\text { (SON) }\end{array}$ & $\begin{array}{c}\text { Summer } \\
(D \mathcal{D F})\end{array}$ & $\begin{array}{c}\text { Autumn } \\
\text { (MAM) }\end{array}$ & $\begin{array}{l}\text { Winter } \\
\text { (FFA) }\end{array}$ & Ann. \\
\hline Western Weddell Sea $\left(60-35^{\circ} \mathrm{W}\right)$ & 10 & 5 & 10 & 15 & 10 \\
\hline Central and eastern Weddell Sea $\left(35^{\circ} \mathrm{W}-20^{\circ} \mathrm{E}\right)$ & 20 & 10 & 20 & 30 & 20 \\
\hline Indian Ocean $\left(20-90^{\circ} \mathrm{E}\right)$ & 15 & 10 & 15 & 20 & 15 \\
\hline Western Pacific Ocean $\left(90-160^{\circ} \mathrm{E}\right)$ & 10 & 5 & 10 & 15 & 10 \\
\hline Western Ross Sea $\left(160^{\circ} \mathrm{E}-160^{\circ} \mathrm{W}\right)$ & 20 & 10 & 20 & 30 & 20 \\
\hline Eastern Ross Sea $\left(160-130^{\circ} \mathrm{W}\right)$ & 15 & 10 & 15 & 20 & 15 \\
\hline Bellingshausen-Amundsen Seas $\left(130-60^{\circ} \mathrm{W}\right)$ & 10 & 5 & 10 & 15 & 10 \\
\hline
\end{tabular}

Notes: The annual mean over the whole Antarctic sea-ice zone is $14.0 \mathrm{Wm}^{-2}$. 

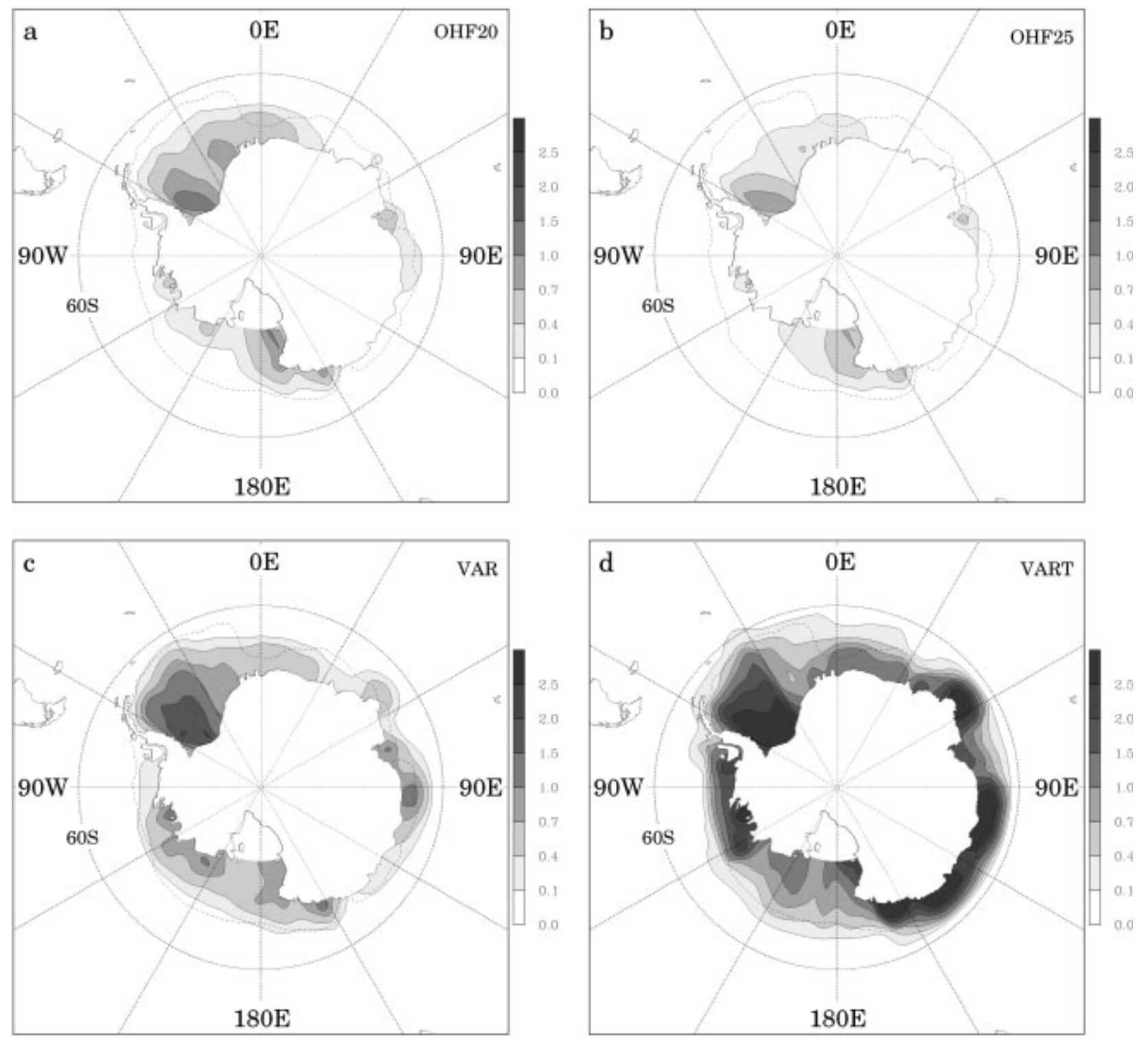

Fig. 2. Simulated sea-ice thickness ( $m$ ) for DFFaverage for (a) OHF20, (b) OHF25, (c) VAR and (d) VART. The dashed line is the observed (SSM/I 1987-95 average) sea-ice edge (defined as 15\% sea-ice concentration).

much sea ice in summer, and for OHF20 and OHF25 there is too little sea ice simulated (see Figs 1 and 2). The simulated sea-ice concentration (not shown) is reasonable compared to $\mathrm{SSM} / \mathrm{I}$ data, but values tend to be $5-15 \%$ higher. The SSM/I gives a mean sea-ice concentration of $46 \%$ for DecemberFebruary (DJF) and 70\% for June-August (JJA). The corresponding simulation is $44-59 \%$ for DJF and $81-82 \%$ for JJA, except for VART which is $80 \%$ for DJF and $85 \%$ forJJA. However, one should bear in mind that there is still some concern that the satellite-estimated sea-ice concentration is too low during winter in regions of thin ice and brash (e.g. Comiso and others, 1997; Worby and Wu, 1998).

The Antarctic sea-ice thickness for the different model simulations for DJF average is shown in Figures 1 and 2. The corresponding simulations for JJA are given in Figures 3 and 4. The observed sea-ice edge (defined as $15 \%$ sea-ice concentration), from SSM/I data (1987-95 average), is the dashed line in the figures. It can be seen that the OHF has a large impact on the simulated Antarctic sea-ice thickness, and that the sea ice is much thicker in VART (thermodynamics only) than in VAR. More extensive sea ice than observations is simulated for OHF0, OHF5 and VART, and less extensive sea ice for OHF20 and OHF25, in almost every sector of the Southern Ocean in summer. The simulation is reasonable for OHF15 and VAR in summer, except that the sea ice simulated in most of the East Antarctic $\left(45-120^{\circ} \mathrm{E}\right)$ is too extensive. This suggests that ice advection plays an important role in ice decay in summer. The sea-ice extent in summer is also sensitive to OHF; an annual mean value of about $15 \mathrm{Wm}^{-2}$ for OHF produces a reasonable sea-ice extent. Unlike the summer sea-ice extent the simulated sea-ice edge in winter is reasonable for all experiments including VART, which implies that the advance of Antarctic sea ice is primarily thermodynamic.

Observations show that most Antarctic first-year winter sea ice is $0.4-1.0 \mathrm{~m}$ thick (e.g. Wadhams and others, 1987; Wadhams, 1994; Worby and others, 1996, 1998). This means that the simulated sea ice in VART is too thick; this may also be true for OHF0 and OHF5. For OHF20 and OHF25 the simulated sea ice is clearly too thin. The simulations for OHF10, OHF15 and VAR appear reasonable.

Table 2 shows the observed sea-ice thickness off East Antarctica $\left(60-150^{\circ} \mathrm{E}\right)$, and the modelled bias of sea-ice thickness (model less observation). The observed values are derived from observations of the undeformed thickness of floes, plus 

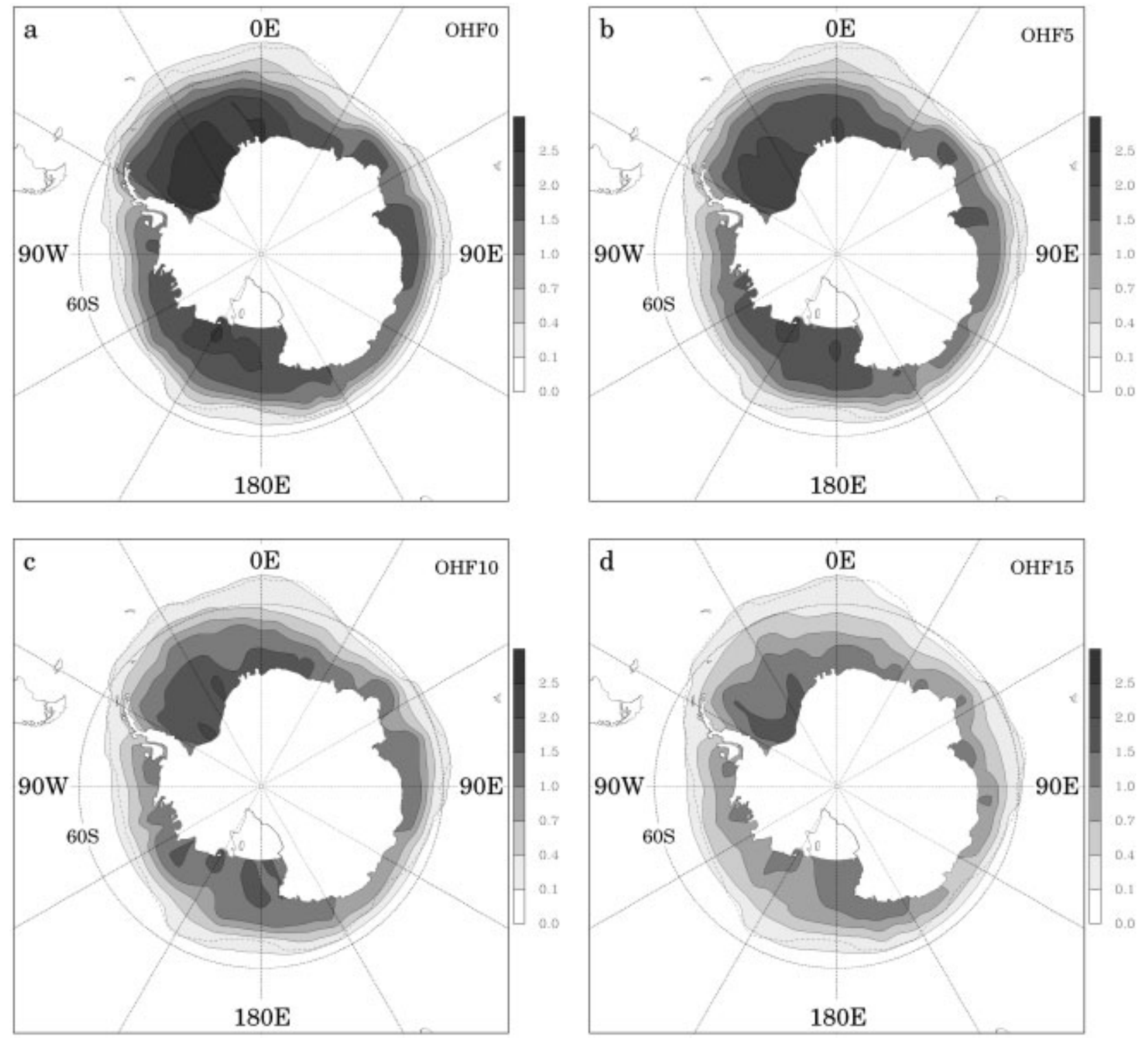

Fig. 3. Simulated sea-ice thickness ( $m$ ) for June-August ( 7 FA) average for (a) OHFO, (b) OHF5, (c) OHF10 and (d) OHF15. The dashed line is the observed (SSM/I 1987-95 average) sea-ice edge (defined as 15\% sea-ice concentration).

the contribution to total thickness due to ridging, estimated by Worby and others (1998) to be an additional $80 \%$ of undeformed floe thickness. The values are also weighted by the open-water fraction to represent the mean over the total ice and leads area. During early autumn (March-April) the mean OHF needs to be about $0-5 \mathrm{Wm}^{-2}$ off East Antarctica in order to match the observed sea-ice thickness; during late winter it should be about $10-20 \mathrm{Wm}^{-2}$. For December, however, relatively high $\mathrm{OHF}$ values $\left(10-15 \mathrm{Wm}^{-2}\right)$ are required within the same region. Although this is less than the value

Table 2. The averaged sea-ice thickness (cm) at 60-150 E from in situ observations for March, April and August-December, and the simulated bias (model less observation) and root-mean-square error (rmse) of sea-ice thickness (cm) for different OHF runs $\left(0-25 \mathrm{Wm}^{-2}\right.$, VAR and VART)

\begin{tabular}{|c|c|c|c|c|c|c|c|c|c|}
\hline Parameter & Mar & $A p r$ & Aug & $\begin{array}{c}\text { Month } \\
\text { Sept }\end{array}$ & $O c t$ & Nov & $D e c$ & Mean & rmse \\
\hline OHF0-OBS & 12 & 10 & 22 & 35 & 61 & 45 & 39 & 32 & 35 \\
\hline OHF5-OBS & -9 & -9 & 12 & 25 & 45 & 31 & 33 & 18 & 27 \\
\hline OHF10-OBS & -8 & -28 & -1 & 15 & 32 & 21 & 15 & 7 & 20 \\
\hline OHF20-OBS & -5 & -33 & -32 & -19 & -2 & -3 & -11 & -15 & 19 \\
\hline OHF25-OBS & -17 & -36 & -37 & -28 & -9 & -14 & -22 & -23 & 25 \\
\hline VAR-OBS & -9 & -11 & -15 & -1 & 22 & 7 & 15 & 1 & 13 \\
\hline VART-OBS & 140 & 124 & 71 & 86 & 106 & 101 & 169 & 114 & 118 \\
\hline
\end{tabular}



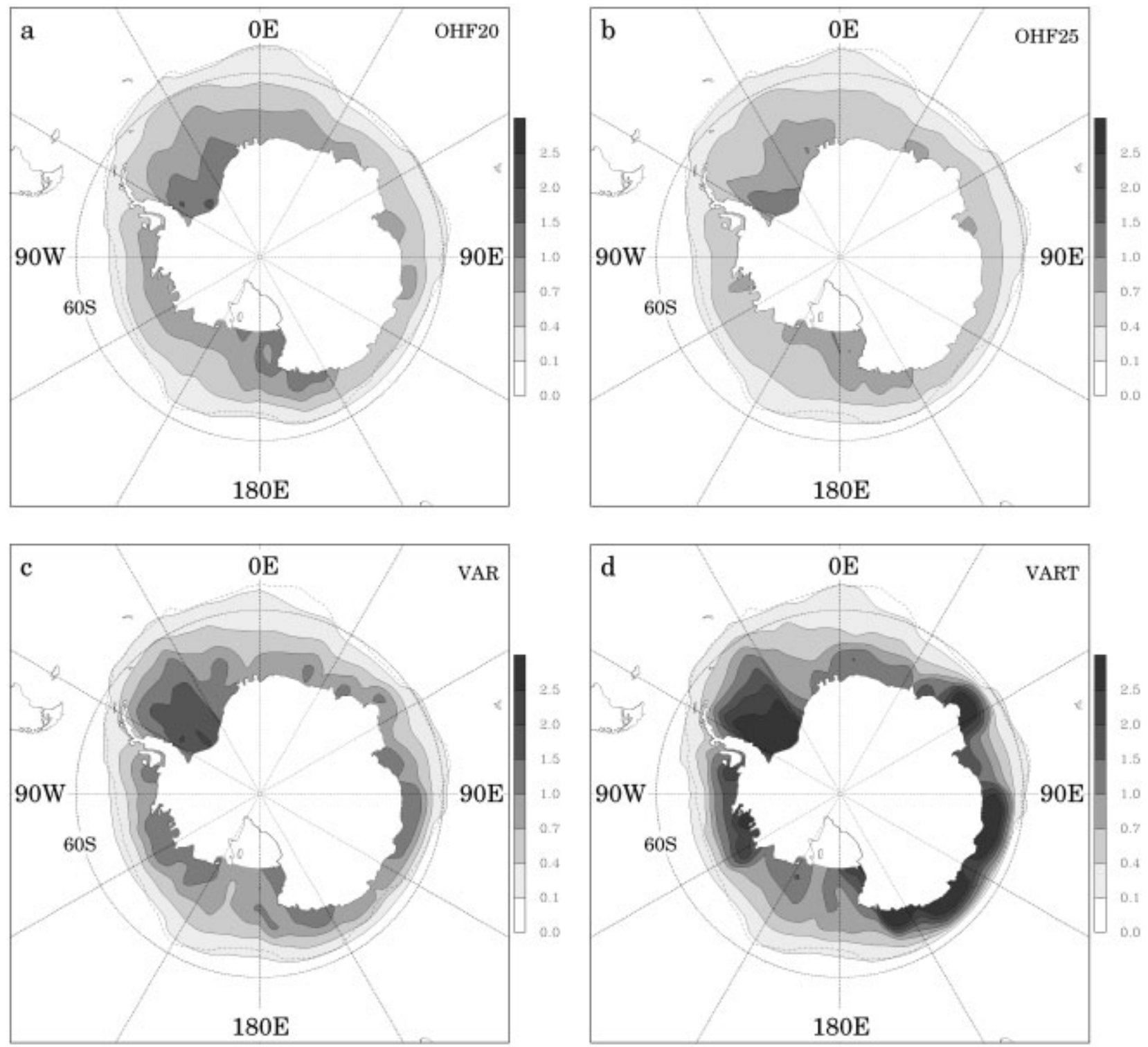

Fig. 4. Simulated sea-ice thickness ( $m$ ) for 7 JA average for (a) OHF20, (b) OHF25, (c) VAR and (d) VART. The dashed line is the observed (SSM/I 1987-95 average) sea-ice edge (defined as 15\% sea-ice concentration).

suggested by Gordon (1981), there is still a question concerning the physical reason for this. Modelling has shown that the $\mathrm{OHF}$ is small in summer because the upper ocean is capped by fresh water from ice melting which effectively stops ocean heat entraining into the surface layer (e.g. Lemke and others, 1990; Stössel, 1992). One may argue that for each month the observations do not cover all the area of $60-150^{\circ} \mathrm{E}$ off East Antarctica as in the model simulation; nevertheless, for the mean ice thickness overall, OHF10, OHF15 and VAR produce reasonable simulations. With statistical analysis, VAR produces the smallest root-mean-square error of all the experiments. For the constant-OHF case, OHF15 produces

Table 3. Dependence of the simulated sea-ice thickness distribution on mean $\mathrm{OHF}$, over the region $66-71^{\circ} \mathrm{S}, 77-110^{\circ} \mathrm{W}$ in the Bellingshausen and Amundsen Seas, August-September. The thickness distribution is given as the percentage of ice in each thickness category $\left(h_{\mathrm{i}}\right.$ in $m$ )

\begin{tabular}{lcccc}
\hline & Openwater & $h_{\mathrm{i}}<0.3$ & $0.3<h_{\mathrm{i}}<0.7$ & $h_{\mathrm{i}}>0.7$ \\
\hline OBS & 9 & 18 & 44 & 29 \\
OHF0 & 10.2 & 0 & 28.8 & 61.0 \\
OHF5 & 9.2 & 7.2 & 29.7 & 53.9 \\
OHF10 & 9.8 & 7.5 & 36.7 & 46.0 \\
OHF15 & 9.9 & 7.9 & 41.4 & 40.8 \\
OHF20 & 10.0 & 7.2 & 44.1 & 6.7 \\
OHF25 & 10.5 & 6.3 & 76.6 & 39.2 \\
VAR & 9.1 & 0.3 & 44.4 & 49.0 \\
VART & 2.0 & & 49.0 & \\
\hline
\end{tabular}


the best simulation. When only thermodynamics is used, the simulated sea ice is too thick.

In August and September 1993, an investigation of sea-ice physics and biology was undertaken in the Bellingshausen and Amundsen Seas in the region $66-71^{\circ} \mathrm{S}, 77-110^{\circ} \mathrm{W}$. Worby and others (1996) estimated a sea-ice thickness distribution in this region from direct measurements. We have calculated the dependence of the simulated sea-ice thickness distribution on the mean $\mathrm{OHF}$, based on the mean ice thickness at each gridcell, over the same region for August-September, which is shown in Table 3. VAR, OHF15 and OHF20 simulate a reasonable sea-ice distribution compared to the observations. However, the model simulates too little thin ice (ice thickness $<0.3 \mathrm{~m}$ ) and too much thick ice (ice thickness $>0.7 \mathrm{~m}$ ) for all experiments, except for OHF25 which shows too little thick ice. This is due to the limitation of the single ice thickness in each gridcell in the model (Worby and Wu, 1998), and also the low spatial resolution of the model. If multiple thicknesses are allowed in a gridcell or the model's spatial resolution is higher, it is expected that the thin-ice simulation can be improved. Again the worst simulation is VART, which shows too little open water in the ice pack compared to observations, due to the lack of sea-ice advection in this simulation.

These simulated results indicate that the $\mathrm{OHF}$ varies not only seasonally but also spatially. The annual mean OHFover the Southern Hemisphere is about $10-15 \mathrm{Wm}^{-2}$, with higher values in winter, which agrees with observations. The results also suggest that sea-ice dynamics plays an important part in the seasonal distribution of sea ice. The advance of Antarctic sea ice is primarily by thermodynamics, but the rapid decay depends critically on ice advection. This supports the findings of Hibler and Ackley (1983), who simulated the seasonal cycle of the Weddell Sea ice.

\section{DISGUSSION AND GONGLUSIONS}

This work has focused on the sensitivity of the Antarctic seaice distribution to $\mathrm{OHF}$ in a coupled atmosphere-sea-ice model, and attempted to define the seasonal cycle of the $\mathrm{OHF}$ in the coupled system. Our results indicate that the magnitude of the $\mathrm{OHF}$ is critical in determining the sea-ice thickness distribution and the summer sea-ice extent. This is in good agreement with other studies (e.g. Geiger and others, 1997). An annual mean OHF of $10-20 \mathrm{Wm}^{-2}$ gives a reasonable sea-ice thickness distribution in the Southern Hemisphere, and agrees with the limited observations of OHF available (Allison, 1981; Gordon and Huber, 1990; Martinson, 1990; McPhee and others, 1996, 1999; Lytle and others, 2000). Values of $0-5 \mathrm{Wm}^{-2}$ for OHF throughout the year will cause the simulated sea ice to be too thick, but when a value of $20-25 \mathrm{Wm}^{-2}$ is used throughout the year, the simulated sea ice is too thin to match observations. Our results also indicate that a larger $\mathrm{OHF}$ is required in winter, which also agrees with observations. The results from our coupled model differ from those with prescribed monthlymean atmospheric forcing (Parkinson and Washington, 1979), but support the findings of Hibler and Ackley (1993) that ice advance is due primarily to thermodynamics but the rapid decay of ice extent depends very much on ice advection. Without advection, sea ice is simulated poorly, being too thick and too compact in all seasons, and too extensive in summer. Observations indicate that the $\mathrm{OHF}$ may vary from one region to another. Our results suggest that the $\mathrm{OHF}$ in the East Antarctic region differs from that in the Weddell Sea: while a mean value of $15 \mathrm{Wm}^{-2}$ is reasonable for East Antarctica, it might be too high for the western Weddell Sea. To test if a seasonally and spatially variable $\mathrm{OHF}$ would improve the simulated sea-ice distribution, we have also run the coupled model with prescribed $\mathrm{OHF}$, based on the limited observations available (VAR). We found that a variable $\mathrm{OHF}$ simulates the sea-ice distribution better than a constant OHF. This supports the earlier work by Geiger and others (1997) who studied the sensitivity of Weddell Sea ice to atmospheric and oceanic forcing.

The OHF has a large impact on the simulated Antarctic sea-ice thickness, which decreases with the increase in OHF. This implies that $\mathrm{OHF}$ is of great importance for simulating the sea-ice distribution. Appropriate values of the $\mathrm{OHF}$ are as important as ice dynamics for the sea-ice model. For fully coupled climate models, which include the ocean, the OHF is prognostic. There is a need for more accurate values of the $\mathrm{OHF}$ from observation to validate the parameterization of the $\mathrm{OHF}$ in the models, and to validate the simulated seaice distribution under the present climate conditions without the use of imposed heat-flux adjustments.

We have demonstrated the importance of the $\mathrm{OHF}$ and also sea-ice advection in the simulated Antarctic sea-ice distribution. However, the OHF is not the only unknown, as there are still some shortcomings in the present model simulations, related to the atmospheric and oceanic forcing. Firstly, there is a lack of explicit ocean-current forcing in the model simulation, which may cause a less realistic sea-ice simulation in some major gyres including the Weddell Gyre. Secondly, there might be some deficiencies in the simulated wind field from the atmospheric GCM (Wu and others, 1997) relative to the synchronous time observations. The simulated sea ice may be constrained by biases of the atmospheric wind and other fields. Thirdly, the $2 \%$ free drift might be too low at some locations, and this may reduce the drift rates of the modelled ice to values which are too low compared to observations. Finally, the single ice thickness used in the model allows only a crude estimation of the real thickness distribution. Nevertheless we have successfully simulated the large-scale seasonal sea-ice distribution of the Antarctic sea ice when a value of OHF close to observed values is prescribed in the model which includes sea-ice advection. In the future we propose to use a sea-ice model which includes more complex physics of sea-ice dynamics (e.g. Hibler, 1979) and a multi-level ice-thickness distribution.

\section{ACKNOWLEDGEMENTS}

We would like to thank J. Turner and one anonymous referee for valuable comments which helped to improve this paper.

\section{REFERENGES}

Allison, I. 1981. Antarctic sea ice growth and oceanic heat flux. International Association of Hydrological Sciences Publication 131 (Symposium at Canberra 1979 - Sea Level, Ice and Climatic Change), 161-170.

Allison, I., C. M. Tivendale, G. J. Akerman, J. M. Tann and R. H. Wills. 1982. Seasonal variations in the surface energy exchanges over Antarctica sea ice and coastal waters. Ann. Glaciol., 3, 12-16.

Allison, I., R. E. Brandt and S. G. Warren. 1993. East Antarctic sea ice: albedo, thickness distribution, and snow cover. F. Geophys. Res., 98(C7), 12,417-12,429.

Boer, G. J. and 13 others. 1992. Some results from an intercomparison of the climate simulated by 14 atmospheric general circulation models. 7. Geophys. Res., 97 (D12), 12,771-12,786.

Budd, W. F. 1991. Antarctica and global change. Climatic Change, 18(2-3), 271-299. 
Budd, W. F., X. Wu and P. A. Reid. 1997. Physical characteristics of the Antarctic sea-ice zone derived from modelling and observations. Ann. Glaciol., $25,1-7$.

Cavalieri, D. J., P. Gloersen, C. L. Parkinson, J. C. Comiso and H. J. Zwally. 1997. Observed hemispheric asymmetry in global sea ice changes. Science, 278(5340), 1104-1106.

Comiso, J. C., D. J. Cavalieri, C. L. Parkinson and P. Gloersen. 1997. Passive microwave algorithms for sea ice concentrations: a comparison of two techniques. Remote Sensing Environ., 60(3), 357-384.

Crane, D. and P. Wadhams. 1996. Sea-ice motion in the Weddell Sea from drifting-buoy and AVHRR data. 7. Glaciol., 42(141), 249-254.

Ebert, E. E. and J. A. Curry. 1993. An intermediate one-dimensional thermodynamic sea ice model for investigating ice-atmosphere interactions. $\mathcal{F}$. Geophys. Res., 98 (C6), 10,085-10,109.

Flato, G. M. and W. D. Hibler, III. 1992. Modeling pack ice as a cavitating fluid. 7. Phys. Oceanogr., 22(6), 626-651.

Geiger, C. A., S. F. Ackley and W. D. Hibler, III. 1997. Year-round pack ice in the western Weddell Sea, Antarctica: response and sensitivity to atmospheric and oceanic forcing. Ann. Glaciol., 25, 269-275.

Gordon, A. L. 1981. Seasonality of Southern Ocean ice. 7. Geophys. Res., 86(C5), 4193-4197.

Gordon, A. and B. A. Huber. 1990. Southern Ocean winter mixed layer. $\mathcal{f}$ Geophys. Res., 95(C7), 11,655-11,672.

Häkkinen, S. 1995. Seasonal simulation of the Southern Ocean coupled iceocean system. 7. Geophys. Res., 100 (C11), 22,733-22,748.

Hanna, E. 1996. The role of Antarctic sea ice in global climate change. Prog. Phys. Geogr., 20(4), 371-401.

Heil, P., I. Allison and V. I. Lytle. 1996. Seasonal and interannual variations of the oceanic heat flux under a landfast Antarctic sea ice cover. F. Geophys. Res., $101(\mathrm{C} 11), 25,741-25,752$.

Hibler, W. D., III. 1979. A dynamic thermodynamic sea ice model. F. Phys. Oceanogr., 9(7), 815-846.

Hibler, W. D., III and S. F. Ackley. 1983. Numerical simulation of the Weddell Sea pack ice. 7. Geophys. Res., 88(C5), 2873-2887.

Ledley, T. S. 1985. Sensitivity of a thermodynamic sea ice model with leads to time step size. f. Geophys. Res., 90 (D1), 2251-2260.

Lemke, P., W. B. Owens and W. D. Hibler, III. 1990. A coupled sea icemixed layer-pycnocline model for the Weddell Sea. 7. Geophys. Res., 95(C6), 9513-9525.

Lytle, V. I. and S. F. Ackley. 1996. Heat flux through sea ice in the western Weddell Sea: convective and conductive transfer processes. 7. Geophys. Res., 101(C4), 8853-8868.

Lytle, V. I., R. Massom, N. Bindoff, A. Worby and I. Allison. 2000. The Wintertime heat flux to the underside of east Antarctic pack ice. F. Geophys. Res., $\mathbf{1 0 5}(\mathrm{Cl} 2), 28,759-28,769$
Martinson, D. G. 1990. Evolution of the Southern Ocean winter mixed layer and sea ice: open ocean deepwater formation and ventilation. 7. Geophys. Res., 95(C7), 11,641-11,654.

McPhee, M. G. and 8 others. 1996. The Antarctic Zone Flux Experiment. Bull. Am. Meteorol. Soc., 77(6), 1221-1232.

McPhee, M. G., S. F. Ackley, C. Kottmeier and J. H. Morison. 1999. Ocean heat flux in the central Weddell Sea during winter. 7. Phys. Oceanogr., 29(6), 1166-1179.

Parkinson, C. L. and W. M. Washington. 1979. A large-scale numerical model of sea ice. 7. Geophys. Res., 84(Cl), 311-337.

Simmonds, I. 1985. Analysis of the "spinup" of a general circulation model. 7. Geophys. Res., 90 (D3), 5637-5660.

Simmonds, I. 1990. Improvements in general circulation model performance in simulating Antarctic climate. Antarct. Sci., 2(4), 287-300. (Correction: Antarct. Sci., 3(2), 1991, 230.)

Simmonds, I. and W. F. Budd. 1990. A simple parameterization of ice leads in a general circulation model, and the sensitivity of climate to change in Antarctic ice concentration. Ann. Glaciol., 14, 266-269.

Stössel, A. 1992. Sensitivity of Southern Ocean sea-ice simulations to different atmospheric forcing algorithm. Tellus, 44A(5), 395-413.

Wadhams, P. 1994. Sea ice thickness changes and their relation to climate. In Johannessen, O. M., R. D. Muench and J. E. Overland, eds. The polar oceans and their role in shaping the global environment: the Nansen Centennial volume. Washington, DC, American Geophysical Union, 337-361. (Geophysical Monograph 85.)

Wadhams, P., M. A. Lange and S. F. Ackley. 1987. The ice thickness distribution across the Atlantic sector of the Antarctic Ocean in midwinter. 7. Geophys. Res., $92(\mathrm{Cl} 3), 14,535-14,552$.

Worby, A. P. and X. Wu. 1998. East Antarctic sea ice: observations and modelling. Ann. Glaciol., 27, 427-432.

Worby, A. P., M. O. Jeffries, W. F. Weeks, R. Morris and R. Jaña. 1996. The thickness distribution of sea ice and snow cover during late winter in the Bellingshausen and Amundsen Seas, Antarctica. 7. Geophys. Res., $101(\mathrm{Cl}), 28,441-28,455$.

Worby, A. P., R. A. Massom, I. Allison, V. I. Lytle and P. Heil. 1998. East Antarctic sea ice: a review of its structure, properties and drift. In Jeffries, M. O., ed. Antarctic sea ice: physical processes, interactions and variability. Washington, DC, American Geophysical Union, 41-67. (Antarctic Research Series 74.)

Wu, X., I. Simmonds and W. F. Budd. 1997. Modeling of Antarctic sea ice in a general circulation model. f. Climate, 10(4), 593-609.

Wu, X., W. F. Budd, V. I. Lytle and R. A. Massom. 1999. The effect of snow on Antarctic sea ice simulations in a coupled atmosphere-sea ice model. Climate Dyn., 15(2), 127-143. 